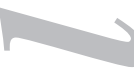

\title{
Nutritional assessment and management in liver transplantation
}

Patients eligible for solid organ transplantation are functionally end-stage regarding the organ to be transplanted. Being chronic patients, they usually display malnutrition to some extent (1). Weight loss and other malnutrition signs are considered predictive factors for poor prognosis regarding the outcome of surgical patients, including patients undergoing a solid-organ transplant $(2,3)$. The presence of malnutrition is associated with increased morbidity and mortality, and higher healthcare costs (4). Major malnutrition causes in patients with advanced liver disease include inadequate dietary intake -from anorexia, from drugs and therapy-related dietary changes, or from disease complications- and main nutrient-related metabolic changes (5).

Regardless of the underlying disease, a diagnosis of malnutrition is established by a combination of various methods: medical record, anthropometric measurements, biochemical parameters, and body composition. As de Luis et al. suggest in this issue of REED (6), end-stage liver disease itself may greatly modify many of these indices. Ideally, accurate body composition techniques such as $\mathrm{K}$ measurement ${ }^{40}$ or deuterium concentration should be used. Unfortunately, such techniques require complex equipments available only in a few centers.

However, such technical limitations do not justify the omission of nutritional assessments in patients eligible for liver transplantation. Nutritional screening tests are a good tool for the initial assessment of a patient's nutritional status, even when they are not specifically indicated for advanced chronic liver disease (7,8). Anthropometric measurements may also be useful, except when water and salt retention are significant (9). In contrast, plasma concentration measurements regarding some proteins are not so useful in these patients. DXA (dual-energy X-ray absorptiometry) is a method for body composition analysis based on the measurement of a body property, rather than a body component. Many hospitals have this instrument to assess bone mineral density, and it also provides sound information on other body components, including fat mass (10). While some experiences with this method have been reported in patients with cirrhosis (11), its accuracy for patients with water and salt decompensation remains to be definitely established. On the other hand, the accuracy of a bioimpedance analysis depends on the applicability of the regression equation relating current resistance through the body to body composition parameters. This method may scarcely sensitive for the detection of brisk water volume changes, particularly in the abdomen. Despite this, some groups advocate for its usefulness in the assessment of patients with advanced liver disease (12).

De Luis et al. have assessed 31 candidates to liver transplantation using nutritional screening tests, anthropometric and biochemical measures, and bioimpedance 
analysis. Overall, patients in this small series had an acceptable nutritional status. These findings are in contrast with those by other authors $(13,14)$ who did find a high malnutrition percentage. This difference may be due to a number of factors: various populations and severities, small sample size, and different etiologies for liver disease. Of 31 patients studied by De Luis et al., disease etiology is other than alcohol use in $41.1 \%$, and $35.5 \%$ are in Child's A or B stage. The transplantation protocol in their hospital may include preoperative nutritional support with specialized dietary counseling and home enteral nutrition when needed. In fact, energy ingestion is over $25 \mathrm{kcal} / \mathrm{kg} / \mathrm{day}$, and protein ingestion exceeds $1 \mathrm{~g} / \mathrm{kg} / \mathrm{day}$ in most cases.

The notion accepted among the various Spanish centers with liver transplantation programs is that malnutrition persists in a relevant percentage of transplant candidates. The incidence of malnutrition varies with the origin of liver disease. Hence, a nutritional status assessment is very useful in all candidates. Those with malnutrition or risk thereof during the waiting period may benefit from specific nutritional treatment. Salt, water or protein restrictions should only be started when needed for complications control. Carbohydrate ingestion before bedtime may be of interest in order to reduce gluconeogenesis. If a dietary analysis shows inadequate energy, protein, zinc, folic acid or fat-soluble vitamin consumption, nutritional supplements to palliate such nutritional deficiencies may be considered. Mixtures containing branching amino acids and carbohydrates would only be indicated for patients developing chronic liver encephalopathy symptoms despite moderate protein intakes. Patients with compensated liver disease may have a positive nitrogen balance with no encephalopathy (15).

Overall, recommendations regarding nutritional supplements among liver transplant candidates are based on expert suggestions rather than prospective, randomized clinical trials. Available results suggest an improvement of nutritional variables, and a trend to decreased mortality; however, samples in these studies are small (16). A preliminary study has shown that liver transplants may be prepared using oral supplements with immunonutrients, which would facilitate nutritional status improvement, and recovery following transplant; they would also reduce post-surgical infection (17). On the other hand, in patients with a transjugular portosystemic shunt enteral nutrition results in greater ammonia levels versus parenteral nutrition, and the parenteral route may have metabolic advantages should some of these patients require artificial nutrition (18).

Once the transplant has been completed, nutritional treatment, together with an appropriate immunosuppressing therapy, should contribute to the prevention and treatment of obesity, diabetes, and dyslipemia, as these metabolic disturbances may commonly develop in such patients (5).

M. León Sanz and M. A. Valero Zanuy

Unit of Clinical Nutrition and Dietetics. Hospital 12 de Octubre. Madrid, Spain 


\section{REFERENCES}

1. Cabré E, Gassull MA. Nutritional aspects of liver disease and transplantation. Curr Opin Clin Nutr Metab Care 2001; 4: 581-9.

2. Alpelgren KN, Rombeau JE, Miller RA, et al. Malnutrition in Veterans Administration surgical patients. Arch Surg 1981; 116: 1059-61.

3. A.S.P.E.N. American Society for Parenteral and Enteral Nutrition Board of Directors and The Clinical Guidelines Task Force. Guidelines for the use of parenteral and enteral nutrition in adult and pediatric patients. JPEN 2002; 26 (Supl. 1): 1SA-138SA.

4. Selberg O, Bottcher J, Tusch G, et al. Identification of high and low risk patients before liver transplantation: A prospective cohort study of nutritional metabolic parameters in 150 patients. Hepatology 1997; 25: 652-7.

5. Patton KM, Aranda-Michel J. Nutritional aspects in liver disease and liver transplantation. Nutr Clin Pract 2002; 17: 332-40

6. De Luis DA, Izaola O, Velicia MC, Sánchez Antolín G, García Pajares F, Terroba MG, et al. Efecto de la ingesta y del estado nutricional en el transplante hepático. Rev Esp Enferm Dig 2006; 98 (1): 6-13.

7. Kondrup J, Allison S, Elia M, Vellas B, Plauth M. ESPEN Guidelines for Nutrition Screening 2002. Clin Nutr 2003; 22: 415-21.

8. Stephenson GR, Moretti EW, El-Moalem H, Clavien PA, Tuttle-Newhall JE. Malnutrition in liver transplant patients: preoperative subjective global assessment is predictive of outcome after liver transplantation. Transplantation 2001; 72: 666-70.

9. Figueiredo FA, Dickson ER, Pasha TM, et al. Utility of standard nutritional parameters in detecting body cell mass depletion in patients with end-stage liver disease. Liver Transpl 2000; 6: 575-81.

10. Plank LD. Dual-energy X-ray absorptiometry and body composition. Curr Opin Clin Nutr Metab Care 2005; 8: 305-9.

11. Fiore P, Merli M, Andreoli A, et al. A comparison of skinfold anthropometry and dual-energy X-ray absorptiometry for the evaluation of body fat in cirrhotic patients. Clin Nutr 1999; 18: 349-51.

12. Pirlich M, Schutz T, Spachos T, et al. Bioelectrical impedance analysis is a useful bedside technique to assess malnutrition in cirrhotic patients with and without ascites. Hepatology 2000; 32: 1208-15.

13. DiCecco SR, Wieners EJ, Wiesner RH, Southorn PA, Plevak DJ, Krom RA. Assessment of nutritional status of patients with end-stage liver disease undergoing liver transplantation. Mayo Clin Proc 1989; 64: 95-102.

14. de la Rubia MA, Serrano Corredor S, López Soriano F, et al. Valoración del estado nutricional de pacientes con enfermedad hepática avanzada que son candidatos a transplante hepático. Nutr Hosp 1994; 9: 163-9.

15. Kondrup J, Nielsen K, Juul A. Effect of long-term refeeding on protein metabolism in patients with cirrhosis of the liver. Br J Nutr 1997; 77: 197-212.

16. Le Cornu KA, McKiernan FJ, Kapadia SA, Neuberger JM. A prospective randomized study of preoperative nutritional supplementation in patients awaiting elective orthotopic liver transplantation. Transplantation 2000; 69: 1364-9.

17. Plank LD, McCall JL, Gane EJ, et al. Pre- and postoperative immunonutrition in patients undergoing liver transplantation: a pilot study of safety and efficacy. Clin Nutr 2005; 24: 288-96.

18. Plauth M, Roske AE, Romaniuk P, et al. Post-feeding hyperammonaemia in patients with transjugular intrahepatic portosystemic shunt and liver cirrhosis: role of small intestinal ammonia release and route of nutrient administration. Gut 2000; 46: 849-55. 
tiempo de espera, pueden beneficiarse de tratamiento nutricional específico. Las restricciones de sal, agua o proteínas deben hacerse sólo si el control de las complicaciones así lo requieren. Puede ser interesante la toma de hidratos de carbono antes de acostarse para disminuir la gluconeogénesis. Si el análisis de la dieta muestra un consumo insuficiente de calorías, proteínas, zinc, ácido fólico, o vitaminas liposolubles, pueden plantearse suplementos nutricionales dirigidos a paliar estas deficiencias nutricionales. Las mezclas de aminoácidos ramificados junto con hidratos de carbono estarían indicadas sólo en aquellos pacientes que desarrollan síntomas de encefalopatía hepática crónica a pesar de consumir proteínas con moderación. Los pacientes con enfermedad hepática compensada pueden tener balances positivos de nitrógeno sin desarrollar encefalopatía (15).

En general las recomendaciones sobre suplementación nutricional entre los candidatos a trasplante hepático se basan en recomendaciones de expertos más que en ensayos clínicos prospectivos y aleatorizados. Los resultados disponibles apuntan a una mejoría de variables nutricionales y una tendencia a disminuir la mortalidad, pero son estudios de muestra pequeña (16). Un estudio preliminar ha mostrado la posibilidad de preparar el trasplante hepático con suplementos orales con inmunonutrientes, que facilitarían la mejora del estado nutricional y la recuperación tras el trasplante, así como reducirían las infecciones postquirúrgicas (17). Por otra parte, en pacientes con shunt porto-sistémico transyugular, la nutrición enteral produce mayores cantidades de amoniaco que la nutrición parenteral, por lo que si alguno de estos pacientes precisara nutrición artificial, la vía parenteral podría tener ventajas metabólicas (18).

Una vez realizado el trasplante, el tratamiento nutricional, junto con la selección adecuada del tratamiento inmunosupresor, deberá contribuir a la prevención y tratamiento de la obesidad, diabetes y dislipemia, puesto que estos trastornos metabólicos pueden aparecer con frecuencia en la evolución de estos pacientes (5).

M. León Sanz y M. A. Valero Zanuy

Unidad de Nutrición Clínica y Dietética. Hospital 12 de Octubre. Madrid 